\title{
Modeling of Schottky Barrier Height and Volt-Amper Characteristics for Transition Metal-solid Solution $(\mathrm{SiC})_{1-x}(\mathrm{AlN})_{x}$
}

\author{
V.I. Altukhov, B.A. Bilalov, A.V. Sankin, S.V. Filipova \\ North-Caucasian Federal University Branch in Pyatigorsk, 56, 40 let Oktyabrya ave., 357500 Pyatigorsk, Russia
}

(Received 15 May 2016; published online 29 November 2016)

\begin{abstract}
Proposed nonlinear defect concentration model of metal-semiconductor contact. It is shown that taking into account nonlinear dependence of the Fermi energy EF defect concentration leads to higher barrier Schottky in 15-25\%. Calculated Volt-Amper characteristics of the diodes are consistent with experiment.
\end{abstract}

Keywords: Schottky barrier, Silicon carbide, Solid solutions, Volt-amper characteristics, Metalsemiconductor transitions.

DOI: $10.21272 /$ jnep.8(4(1)).04003

PACS numbers: 73.30. + y, 85.30.Hi

The paper considers a simple non-linear contact model defects on the concentration of metalsemiconductor Schottky barrier is formed when superficial defective $E_{i}$, States localized at the interface. It is shown that taking into account nonlinear dependence of the Fermi energy EF defect concentration leads to higher barrier Schottky in 15$25 \%$. The calculated barrier heights are used for analyzing current characteristics of structures $\mathrm{M} /(\mathrm{SiC})_{1-x}(\mathrm{AlN})_{x}$. The calculation results are compared with experimental results.

The potential barrier height Schottky barrier $\Phi B$ to contact metal-semiconductor Schottky diodes parameter is the most important, field effect transistors and other elements (Instrumentation) power electronics with the superficial barrier structures. Therefore, the study of Schottky barrier in structures on the basis of new and under-studied semiconducting materials still remains an urgent task of semiconductor physics. In this regard, the undoubted interest structure: metal (M: Ni, Al, Mo, Au)/ solid solution of silicon carbide with aluminum nitride $\left((\mathrm{SiC})_{1-x}(\mathrm{AlN})_{x}\right)$, in particular $\mathrm{Al} / n-(\mathrm{SiC})_{1-x}(\mathrm{AlN})_{x}[1,2]$.

The potential barrier height calculation $\Phi B$ for $\mathrm{Al} / n-(\mathrm{SiC})_{1-x}(\mathrm{AlN})_{x}$ on the generalized theory of Bardeen and Schottky-Motta [2,3] never gave a credible agreement with experiments in the field of small surface densities of States [1,2]. However, earlier in the works $[4,5]$ was offered a fairly simple model contact metal $(\mathrm{M})$ - semiconductor $(n-4 \mathrm{H}-\mathrm{SiC})$ with localized at the surface States of defects Ei (BSLD-model). While Volt-Amper characteristics (VACH) diodes Ni/4H-SiC $(x=0)$ with Schottky barrier (SB) good agreement with experiments [6].

In this paper, we developed a model BSLD $[4,5,7]$ and are the results of the simulations and calculations of the barrier height Schottky contact $\mathrm{M} /(\mathrm{SiC})_{1-x}(\mathrm{AlN})_{x}$ with different content $x$. Calculating Volt-Amper characteristics type structure $\mathrm{Al} / n-(\mathrm{SiC})_{1-x}(\mathrm{AlN})_{x}$ as a function of various system parameters $(U-$ voltage electric field, $T$ - temperature, - bandgap, $x$-dependent concentration AlN in solid solution, $\mathrm{Ni}$ - density (concentration) of isolated States defects per unit of surface, $E_{i}$ - surface localized defect status). The results of the calculations are compared with the experimental results for structures $\mathrm{Al} / n-(\mathrm{SiC})_{1-x}(\mathrm{AlN})_{x}$.
The paper considers a modified surface concentrations Schottky barrier model State. Are results of calculations of Schottky barrier with localized in the area of contact conditions defects (BSLD $[4,5]$ ), but in a higher concentration (nonlinear) defects $\left(\mathrm{Ni}=c \times 10^{13} \mathrm{sm}^{-2} \mathrm{eV} ; c=0\right.$-30). In this model, along with the concentration of defects $\mathrm{Ni}$ enter the numbers filling $n x(c)$, defined as Gamiltone operation (2), which leads to a better agreement with the Schottky barrier value experience when $\mathrm{Ni}<10^{13}$ $\mathrm{sm}^{-2} \mathrm{eV}^{-1}$. Then the barrier height is determined by the formula $[3,6]$ :

$$
\begin{aligned}
& \Phi_{B}^{x}(c)=\Phi_{m}-\chi+\Delta \Phi_{x}(c) \\
& \Delta \Phi_{x}(c)=4 \pi\left(e^{2} / 4 \pi \varepsilon_{0} \varepsilon\right) \lambda N_{i} n_{x}(c)
\end{aligned}
$$

Here $\Phi_{m}$ - work function of metal, $x$ - the electronic affinity, $\Delta \Phi_{x}(c)$-potential barrier on contact due to tunneling of electrons between metal and localized kvazi-level, $\lambda$-the thickness of the double layer dielectric permeability $\varepsilon_{0} \varepsilon, \mathrm{Ni}$ - isolated defect states density, $n_{x}(c)$-number of filling a localized level $E_{i}$ с полушириной $\Gamma=\pi \rho V(V-$ hybridization energy of metals and localized states), $\rho$-continuous, assumption, density State of metal, EF - Fermi energy.

Then the semiconductor located in contact with metal, characterized by superficial defective states $|d\rangle$, energy which $E_{i}$ lie in the forbidden zone. Interaction level $|d\rangle$ with metal that can be described is operator Gamiltone of Anderson [4, 7]:

$$
H=\sum_{k} \varepsilon_{k} c_{k}^{+} c_{k}+E_{i} d_{i}^{+} d_{i}+V \cdot \sum_{k}\left(c_{k}^{+} d_{i}+\text { h.c. }\right) \text {. }
$$

Here $\varepsilon_{k}$ - the energy of the electrons in the metal; $V-$ matrix element hybridization of metal $\mid k>$ and defective $\mid d>$ states; $c+k$-operator birth electron in state $|k\rangle ; d_{i}{ }^{+}$-operator birth electron in state $|d\rangle$.

Assuming that the level of localized defective condition $|d\rangle$ overlaps with the broader zone of conductivity of metal is determined by the number of its filling $n d=n_{x}(c)$ :

$$
n_{x}(c)=(1 / \pi) \cdot \operatorname{arccot}\left(\left(\mathrm{E}_{i}-\mathrm{E}_{F}\right) / \Gamma\right)
$$


Consider that the position of EF relative ceiling valence band of the semiconductor bandgap with ( $=3.3 \mathrm{eV}, a=0.56, b=3.86[2,8]$ ), determined by the ratio of [4]:

$$
\mathrm{E}_{F}=\chi+\mathrm{E}_{g}^{x}-\Phi_{m}-\Delta \Phi_{x}(c) .
$$

Then for the potential barrier height Schottky $\Phi_{x} B$ и $n_{x}(c)$ по (3) и (1) taking into account the non-linear concentration with components, we obtain [7]:

$$
\Gamma \delta_{x}(c)=p-\left(1-\xi_{i}\right) \mathrm{E}_{g}^{x}+k \eta c(1-c v)
$$

$n_{x}(c)=(1 / \pi) \cdot \operatorname{arc} \cot \delta x(c)$,

$$
\Phi_{B}^{x}(c)=p+k \eta c 2 n_{x}(c)
$$

where $\eta=0.5 \div 2.0 ; k=0.272$ and for values $E F=E_{g} / 2$, and $\Gamma=0.5 \div 2.0$ value: $\tau=2 / \pi \Gamma, p=\Phi m-x$, and for $\mathrm{Al}$ in $\mathrm{SiC}-\mathrm{AlN}$. The results of calculations on (5)-(6) Schottky barrier height as a function of the parameters of nonlinear models $\xi i, x$ and $c$ presented in figures 1-4. When $v=0$ formula (5)-(6) give initial results in linear models with (BSLD-model) $[4,5]$.

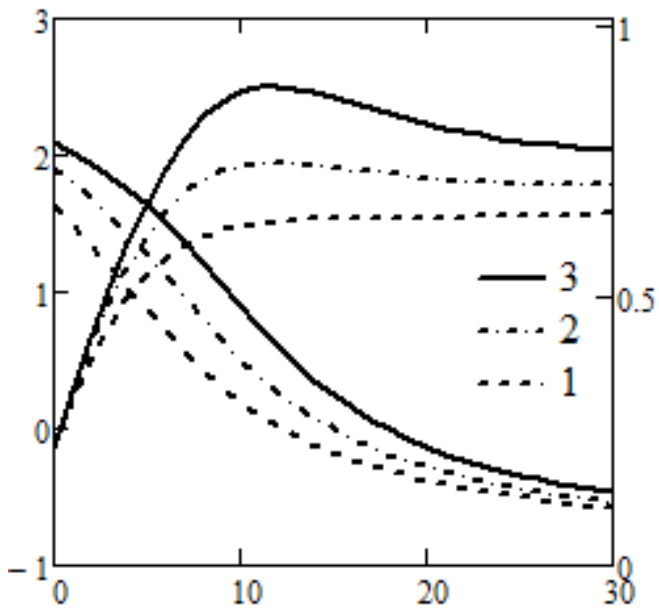

a). When $E g=3.3$ and $E i=\xi i E_{g}(\xi i=0.3 ; 0.5 ; 0.7), v=1 / 200$, for curves 1, 2 and 3 accordingly
2. Schottky barrier height calculation $\Phi B_{x}$ for diodes based on SiC-AlN. Formula (5)-(6) allow you to compare the calculations and conclusions of this work with the results obtained in the framework of generalized theory Badrina and Schottky-Motta [3]. Analysis of the results of this work BSLPS model is generally consistent with the results obtained in the two above mentioned models BSLD (localized defects $[4,5])$ and generalized model Bardeen and SchottkyMotta [2,3]. This is in spite of the different approach to the nature of the Schottky barrier $\Phi B x$ type structures $\mathrm{M} / n-\mathrm{SiC}: \mathrm{AlN}$ по BSLD $[5,7]$ and generalized model $[2,3]$. The transition from linear iteration over $\mathrm{c}$ to the quadratic in $\mathrm{EF}$ and non-linear for $\Phi B_{x}$ and $n_{x}(c)$ Schottky barrier leads to increased from 15 до $25 \%$.

Fig. 1 presents the results of Schottky barrier values dependency analysis $\Phi B_{x}$ and $n_{x}$ the concentration of defects $\mathrm{c}$ and from depth levels $E_{i}$ (Fig. 1a) and from the decomposition $v$ (Fig. 1 b). This dependence has been received by the equations (5) and (6) for $\Phi_{x} B$ and $n_{x}(c)$ from the composition $x$ when $x=0.2 ; 0.5 ; 0.7$.

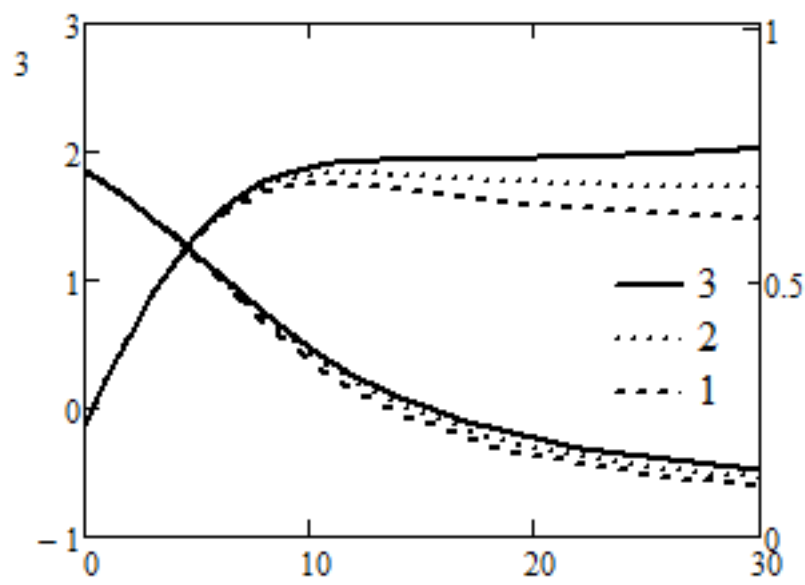

b). When $E_{i}=0.5 E_{g} v=1 / 120 ; v=1 / 200 ; v=1 / 700$ for curves 1,2 and 3 accordingly

Fig. 1 - Dependence of barrier height Schottky $\Phi_{x} B$ (a) and numbers fill the defect states $n_{x}(c)$ the concentration of defects $c$ and the composition of the $x$ (a) and parameter values $v(\mathrm{~b})$ for system $n-\mathrm{Al} / p$-(SiC) $)_{-x}(\mathrm{AlN})_{x}$

3. Current-voltage characteristics $n-\mathrm{Al} / p-(\mathrm{SiC})_{1-}$ ${ }_{x}(\mathrm{AlN})_{x}$ diodes. Formula (5) and (6) for different values of the system parameters $n-\mathrm{Al} / p-(\mathrm{SiC})_{1-x}$ $(\mathrm{AlN})_{x}\left[T, E_{q}^{x}, E_{i}, \Phi_{B_{0}}, n, c, x\right]$ used when calculating the current dependencies $I(V)$ According to the classical theory of emission termo-elektron diode voltage $V[1,10]$ :

$$
\begin{aligned}
& I(V)=s A T^{2} \cdot \exp \left(-\frac{\Phi_{B}^{X}(c)}{k T}\right) \cdot\left[\exp \left(\frac{q V}{n k T}\right)-1\right]= \\
& =I_{0} \cdot\left[\exp \left(\frac{q V}{n k T}\right)-1\right] .
\end{aligned}
$$

It is known that there are qualitative similarity of characteristics of Schottky Barrier diodes with and ordinary $p-n$ transitions [10]. In particular on the experiences observed the similarity of some characteristics of the diode type $4 \mathrm{H}-\mathrm{SiC}[1], n-\mathrm{SiC} /$ $p$-(SiC $)_{1-x}(\mathrm{AlN}) x[8,9], n-\mathrm{Al} / p-(\mathrm{SiC})_{1-x}(\mathrm{AlN})_{x}[2] . \quad$ In the classical theory of Schottky barrier height is considered to be unchanged and used its effective value $\Phi B_{0}$. Fig. 2 shows the current-voltage characteristics for $\Phi B_{0}=1.1 ; 1.26 ; 1.29 ; 1.4$; that meets the the LEDs on the $\mathrm{Ni}, \mathrm{Al}, \mathrm{Mo}, \mathrm{Au}$ and for model values $\Phi B_{0}=1.7$ : curves $1,2,3,4$ and 5 accordingly.

Current values $I(U)$ when $\mathrm{n}=1$ and 2 presented in Fig. 3. There's also a marked data experiences $[2,8]$. Observed at high voltages $(U>1 \mathrm{~V})$ Figure 3 discrepancy theory with experiment apparently connected with the change in size and shape of the potential barrier at the transition or the inclusion of other mechanism of current transport, for example, 


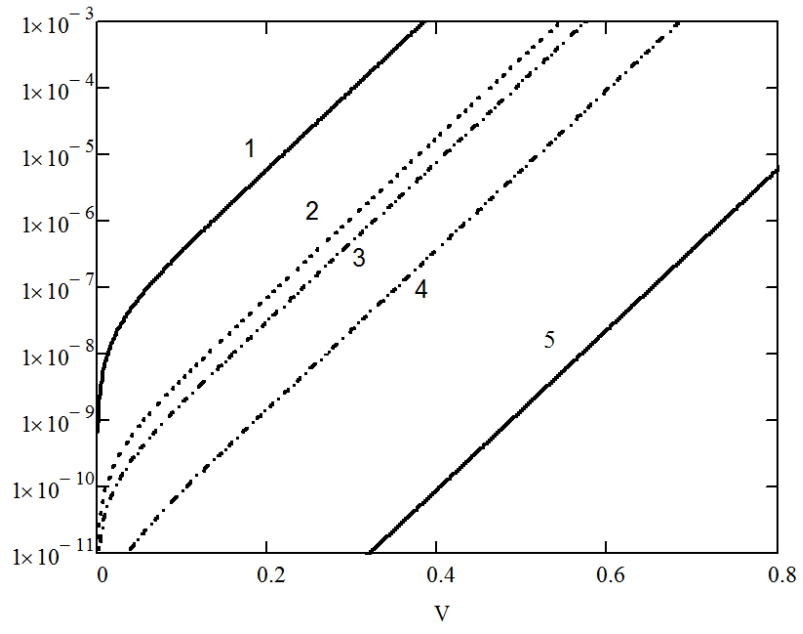

Fig. 2 - Direct Current-voltage characteristics for $\mathrm{Ni}, \mathrm{Al}, \mathrm{Mo}, \mathrm{Au}$ (and $\Phi B_{0}=1.7 \mathrm{eV}$ ) for $n-\mathrm{M} / p-(\mathrm{SiC})_{1-x}(\mathrm{AlN})_{x}$ with $\Phi B_{0}: 1-1.1 ; 2-$ $1.26 ; 3-1.29 ; 4-1.4$ and $5-1.7 \mathrm{eV}$ accordingly

with tunneling of holes through the barrier in a Valence zone [8,9]. Fig. 4 direct line Current-voltage characteristics lists as a function of composition $\mathrm{x}$ for values of concentration of defects $c=4$ and 5 ; $E_{i}=0.5 E_{g}$ and with voltages $U=0.10 ; 0.15 ; 0.18$ $0.20 \mathrm{~V}$ accordingly. According to $I(U)$ from the composition $x$ when $x$ order 0.075 curves of direct current $I(U, x)$ reach the maximum, obviously related to the behavior of the bandgap of the whole. In general data calculations on figures 1-4 are consistent with those experiments $[2,8,9]$ and other authors calculations $[2,4,5]$. Dependence of direct current from a concentration of surface States with different values of the depth of the localized level $\mathrm{Ei}$ is presented in Fig. 5. Minimum curve 2 in from about 12 is associated with a corresponding maximum Schottky barrier height as a function of the concentration of defects. (Fig. 1a).

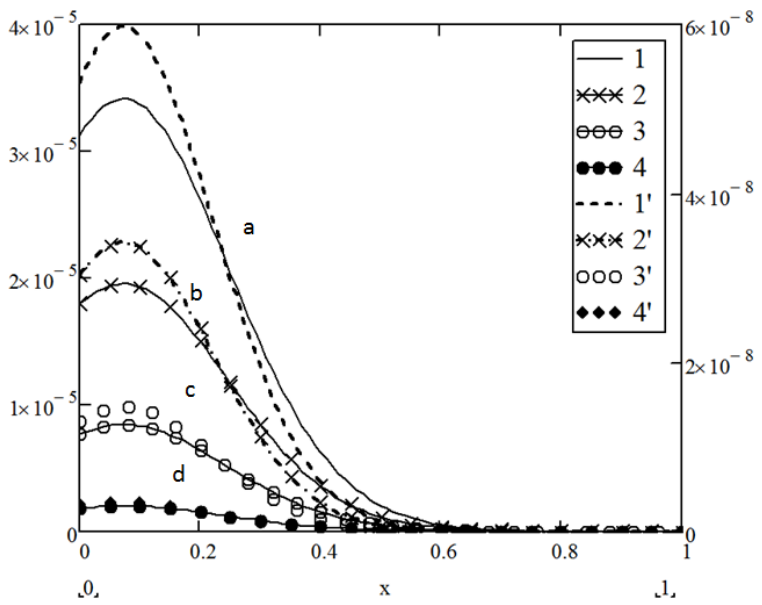

Fig. 4 - Direct current-voltage characteristics as a function of composition for the concentration of defects $c: 1,2,3,4 c=4$; and $1^{\prime}, 2^{\prime}, 3^{\prime}, 4^{\prime} \quad c=5$ and voltages $U$ : a $-0.10 ; \mathrm{b}-0.15$; $\mathrm{c}-0.18 ; \mathrm{d}-0.20 \mathrm{~V}$

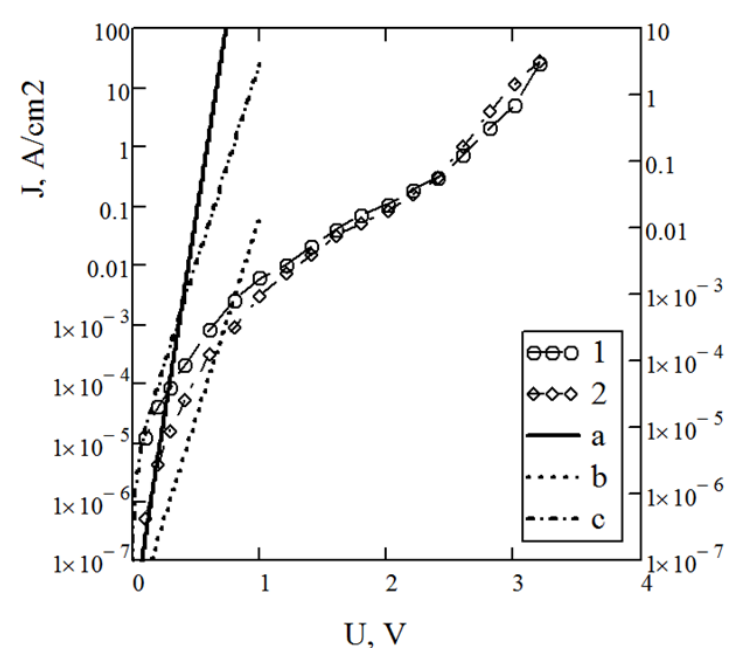

Fig. 3 - Direct Current-voltage characteristics $n-\mathrm{Al} / p-(\mathrm{SiC})_{1}$ ${ }_{x}(\mathrm{AlN})_{x}$ when $T=293 \mathrm{~K}$ : curve $1-x=0.10(n=1-$ curve a, $n=2-\mathrm{b})$; curve $2-x=0.15(n=2-\mathrm{c}) ; 1$ and $2-$ experimental data on $[2,8]$

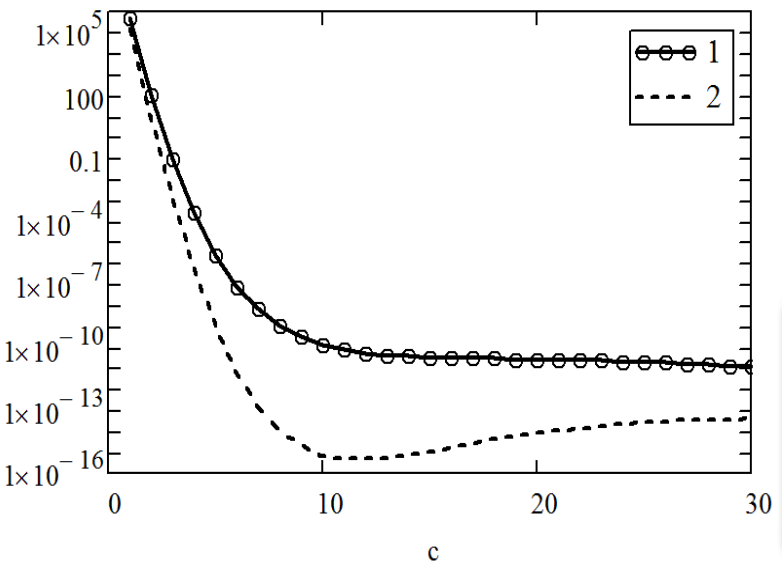

Fig. 5 - Dependence of direct current $I(U)$ the concentration of surface defects c with different values $E_{i}$ : $1-E_{i}=0.3 E g$, $2-E_{i}=0.5 E_{g}$

In the work the model of Schottky barrier with localized at the surface with a non-linear conditions on concentration of defects of the Fermi energy EF. Schottky barrier height calculated under the proposed model for structures $\mathrm{Al} / n-(\mathrm{SiC})_{1-x}(\mathrm{AlN})_{x}$ consistent with the experimental results $[1,3,6]$. The proposed model analyzes the behavior of the Schottky barrier height and current-voltage characteristics of the structures $\mathrm{Al} / n$ - $(\mathrm{SiC})_{1-x}(\mathrm{AlN}) x$ from the system settings: applied voltage electric field (U), temperature $(T)$, bandgap solid solution $(\mathrm{SiQ})_{1-}$ ${ }_{x}(\mathrm{AlN})_{x}$ from the composition of the solid solution $(x)$, the concentration of isolated States defects (Ni) and energy values of surface localized state (Ei).

Using the calculated on BSLPS- models values are built current-voltage characteristics structures $\mathrm{Al} / n$-(SiC) ${ }_{1-x}(\mathrm{AlN}) x$ according to the classical theory of termo-elektronics diode issue. Theoretical currentvoltage characteristics in the field of small currents and voltages are in good agreement with experimental current-voltage characteristics for such structures. A 
method of induction heating modes control algorithm for growing high-voltage heterostructures, layers based on silicon carbide [11]. Received samples used for manufacturing systems with contacts of metal solid solution of silicon carbide Schottky barrier.

\section{REFERENCES}

1. П.А. Иванов, И.В. Грехов, О.И. Коньков, А.С. Потапов, Т.П. Самсонова, Т.В. Семенов, ФТП 45, 1427 (2011) (P.A. Ivanov, I.V. Grekhov, O.I. Kon'kov, A.S. Potapov, T.P. Samsonova, T.V. Semenov, Semiconductors 45, 1427 (2011)).

2. М.К. Курбанов, Ш.М. Рамазанов, Б.З. Мехтиев, Материаль IV-й Всесоюзной конферениии "Физическая электроника", 175 (Махачкала: 2006) (M.K. Kurbanov, Sh.M. Ramazanov, B.Z. Mekhtiyev, Materialy IV-y Vsesoyuznoy konferentsii "Fizicheskaya elektronika", 175 (Makhachkala: 2006)).

3. С. Зи, Физика полупроводниковых приборов (Мир: М.: 1984) (S. Zi, Fizika poluprovodnikovykh priborov (Mir: M. 1984)).

4. С.Ю. Давыдов, А.А. Лебедев, С.К. Тихонов, ФТП 31, 597 (1997) (S.Yu. Davydov, A.A. Lebedev, S.K. Tikhonov, Semiconductors 31, 597 (1997)).

5. С.Ю. Давыдов, А.А. Лебедев, О.В. Посредник, Ю.М. Тайров, ФТП 35, 1437 (2001) (S.Yu. Davydov, A.A. Lebedev, O.V. Posrednik, Yu.M. Tayrov, FTP 35, 1437 (2001)).

6. В.И. Алтухов, А.В. Санкин, О.А. Митюгова, Обозрение прикладной и промышленной математики 17, 246 (2010) (V.I. Altukhov, A.V. Sankin, O.A. Mityugova, Obozreniye prikladnoy $i$ promyshlennoy matematiki $\mathbf{1 7}$, $246(2010))$
7. В.И. Алтухов,

А.В. Санкин,

М.Н. Дядюк, И.С. Касьяненко, О.А. Митюгова, С.В. Филиппова, Обозрение прикладной и промыщленной математики 19, 111 (2012) (V.I. Altukhov, A.V. Sankin, M.N. Dyadyuk, I.S. Kas'yanenko, O.A. Mityugova, S.V. Filippova, Obozreniye prikladnoy $i$ promyshlennoy matematiki $\mathbf{1 9}$, 111 (2012))

8. М.К. Курбанов, Б.А. Билалов, Г.К. Сафаралиев, Ш.М. Рамазанов, Неорганические материальь 43, 1 (2007) (M.K. Kurbanov, B.A. Bilalov, G.K. Safaraliyev, Sh.M. Ramazanov, Neorganicheskiye materialy 43, 1 (2007)).

9. Н.П. Исмаилова, Н.В. Офицерова, Г.К. Сафаралиев, Мониторинг. Наука и Технологии 1, 117 (2009) (N.P. Ismailova, N.V. Ofitserova, G.K. Safaraliyev, Monitoring. Nauka i Tekhnologii 1, 117 (2009)).

10. А.И. Лебедев, Физика полупроводниковых приборов (Физматлит: M.: 2008) (A.I. Lebedev, Fizika poluprovodnikovykh priborov (Fizmatlit: M.: 2008)).

11. И.С. Касьяненко, А.В. Санкин, М.Н. Дядюк, В.И. Алтухов, Высокие технологии, эконолика, пролышленность. T.2, Часть 1 (СПб.: 2012) (I.S. Kas'yanenko, A.V. Sankin, M.N. Dyadyuk, V.I. Altukhov, Vysokiye tekhnologii, ekonomika, promyshlennost'. T.2, Chast' 1 (SPb.: 2012)). 